\title{
Questionnaire: Loss of Entertainment in Spanish Futsal (PEFSE)-Results Analysis
}

\author{
J. Cachón-Zagalaz ${ }^{1, *}$, P. Valdivia-Moral ${ }^{2}$, A. Lara-Sánchez ${ }^{1}$, M. L. Zagalaz-Sánchez ${ }^{1}$, D. Berdejo-del-Fresno ${ }^{3,4}$ \\ ${ }^{1}$ University of Jaén, Jaén, Spain \\ ${ }^{2}$ University of Huelva, Huelva, Spain \\ ${ }^{3}$ The Football Association, London, England \\ ${ }^{4}$ Sheffield FC Futsal \\ *Corresponding author: jcachon@ujaen.es
}

Received September 23, 2013; Revised December 29, 2013; Accepted January 09, 2014

\begin{abstract}
In the absence of questionnaires addressing the analysis of the rule's change in futsal and the need to find an instrument that is capable of carrying out this objective, the aim of this study is to design and develop a questionnaire to assess the loss of entertainment in futsal. To do this, the sample consisted of 279 subjects with roles as a coach, player, physiotherapist, amateur referee and journalist since all of them are part of the sport. The instrument is based on the new rules imposed by FIFA in the kick-in and corner and their impact on the show. This descriptive cross-sectional study where is designed and implemented a closed-responses ad hoc questionnaire to subjects related with futsal in the first category to obtain objective information was undertaken. The analysis of data showed satisfactory results in terms of reliability and validity. It can be concluded that this scale is valid and reliable instrument to analyze changes in the rules of futsal.
\end{abstract}

Keywords: futsal, rules of the game, spectacle, subjects, questionnaire

Cite This Article: J. Cachón-Zagalaz, P. Valdivia-Moral, A. Lara-Sánchez, M. L. Zagalaz-Sánchez, and D. Berdejo-del-Fresno, "Questionnaire: Loss of Entertainment in Spanish Futsal (PEFSE)-Results Analysis." American Journal of Sports Science and Medicine, vol. 2, no. 3 (2014): 83-87. doi: 10.12691/ajssm-2-3-3.

\section{Introduction}

The fast football, indoor soccer or ice football, as it is known in the United States, has its home in Canada almost two centuries ago [1,2]. It was developed as an alternative in places with harsh winters to allow soccer practitioners to continue playing. They did in a wooden floor over the ice hockey court [3]. However, as currently known, futsal (FS) originated in Uruguay in schools, developing the modern version from 1930 onwards, when Professor Juan Carlos Ceriani defines the times and rules. It was played on a basketball court with 5 players on each team. This version will be adopted as the official by the FIFA and, in the opinion of most experts, offers the best conditions for the football development of children.

This research is situated within the social sciences and sports. It has analytical and descriptive nature of sociometric data, such as Rincón, Arnal, Latorre and Sans [4] point, it fits into the constructivist paradigm, within the scope of collective contact sports that aims to demonstrate that subjects related with Futsal such as spectators, fans, players, coaches, referees, journalists, managers and physiotherapists, saying that the show is no longer as attractive as it was before 2006 [5]. At this point it should be noted that Spain has been 2 times World Champion (Guatemala'00, China Taipei'04) 6 times European Champion (Spain'96, Russia'01, Czech Republic'05 ,
Portugal'07, Hungary '10, Croatia'12), 7 times IV Nations Tournament Champion (Italy'91, Belgium'93, Holland'94, Spain'95, Holland'97, Spain'98, Spain'10), 2 times FIFA Champions (Singapore 1997 and 2001); 1 time Grand Prix Champion (Brasil'10) 2 times Runners up in the World Championships (Spain'96, Brasil'08) and 1 time Runners up in the European Championships (Spain'99).

According to Cachón [6], the publication of the Laws of FS by the Royal Spanish Football Federation (RFEF), the President thereof, Ángel María Villar Llona states that [7]: For many years, the FIFA (Fédération Internationale de Football Association) has allowed that the FS were practiced with different game rules in order to promote its development and not to hinder its progress. Currently, it has reached a stage of development such that the most suitable for its future is permanently unify and thus help the sport to be played under the same Game Rules. With the unification of the Laws, recognition and dissemination of this activity between the media and the public will be improved, and the training of coaches, players and referees will be optimized as they will not have to adapt to variations when participating in international competitions.

For all the above, FIFA decided that the 2006-2007 season, all member associations, began their FS competitions under the FIFA FS Laws of the Game.

Due to rules change imposed, this research is justified by the comparative study of the futsal rules prior to 2006 and the rules applied since then until now (2013) in Spain, 
the so-called "FIFA rules". The application of the new rules in Spain, involves a comparison and further analysis as global rules (FIFA) did not apply in Spain and the game had its own characteristics that made it more dynamic and spectacular.

In the literature review, studies in this field have not been found. However, the Teseo Database, only three doctoral theses analyzing the FS appear, but none of them refers to the rules, before or after 2006. In the first, Bortoli [8] discusses the cognitive abilities in futsal, indispensable for the development of a team sport and to implement strategies for throw-ins. The second, Jiménez-Jiménez [9], takes a praxeological study of the structure of the teaching situations in cooperation/opposition sports with common space and simultaneous participation: handball and FS. Finally, the study of Barbero Álvarez [10] explains the development of a photogrammetric system and its synchronization with the heart rate records for the analysis of competition in team sports.

In specialized sport journals, particularly in the futsal expert magazine, Revista Fútbol-Táctico. A football and futsal professional journal, there are three papers that could in any way relate to this study. The first two signed by the Departmento Técnico [7] and the FIFA FUTSAL [11], state about the futsal rules review. Both are completely consistent, except the first paragraph of the first study dating back to 1999. The content says the review is subject to the approval of the member associations, provided that the principles of these Laws are respected. In the same magazine, it highlighted for the interest of this research the article of López Hierro [12] dealing with set-pieces of El Pozo Murcia Futsal Team (Spanish first division). Referred to the set-plays of 200607, the article focuses on three sections: the first one on the corners, the second with the throw-ins/kick-ins and third one on free kicks with wall, although the analysis of the throw-ins is purely technical and does not address the social impact of these rules.

Summaries were revised up to ten years ago, of the scientific, academic and sports content journals, often used in our Spanish community whose most recent numbers collected large amount of articles on football, which could be a reference to our study. However they do not devote any attention to the regulations or allude to futsal. The few articles talking about futsal, relate to sports training and fitness. There are also countless articles for futsal on the internet; however, none of them refers directly to our research problem.

Among the rules that were modified to adapt our rules to the international one, highlight two that are considered as the most determining factors of game development and the loss of its dynamic and spectacular character. These are the kick-ins and corner kicks.

Thanks to the theoretical review the importance of rules change in futsal can be seen. Thus, the existence of a tool that enables to measure the opinions of the leading subjects of the sport is essential for further analysis. Therefore, the aim of this study is to design and develop a questionnaire to assess the loss of entertainment in futsal. This instrument will be useful to all subjects involved in this sport (players, referees, coaches, managers, physiotherapists and spectators).

\section{Methods}

\subsection{Research Design}

The context is the Spanish futsal and the changes that it has suffered in Spain by following the Laws of the Game imposed in 2006. The study is located within the ex post facto or experimental methods and seeks the views of the subjects involved. A quantitative methodology has been used, because the characteristics research -descriptive method- is suited to the subject matter. It has been completed with qualitative techniques whose exposure has been elsewhere [13]. The phases that were followed were:

1. Project design/preparation and goal setting.

2. Design ad validation of the instrument: "Loss of Entertainment in Spanish Futsal: change of the corner and throw-in/kick-in rules" (in Spanish: Pérdida del espectáculo en fútbol sala español: cambio de regla en saque de banda y córner (PEFSE)).

3. Information collection, data analysis and issuance of findings and conclusions.

4. Writing report.

\subsection{Participants}

The subjects of this study has been the participants (players, fans, coaches, managers, referees, physiotherapists and journalists) of the XX Spain Futsal Cup Championship, held in Granada during the months of February and March 2009. The sample was randomly selected according to a probabilistic extraction procedure [14]. Specifically, the random cluster sampling was use since the sampling unit is a group of elements of the population.

The following table shows the subjects' characteristics, the corresponding sample and the percentage of the population involved.

Table 1. Percentage distribution of samples

\begin{tabular}{cccc}
\hline Participants & Population & Sample & $\%$ \\
\hline Coaches & 9 & 9 & 100,0 \\
Players & 104 & 67 & 64,4 \\
Managers & 10 & 1 & 10,0 \\
Referees & 16 & 9 & 56,3 \\
Fans & 740 & 185 & 25,0 \\
Physiotherapists & 8 & 2 & 25,0 \\
Journalists & 15 & 6 & 40,0 \\
Total & 902 & 279 & 30,9 \\
\hline
\end{tabular}

Due to the instability of the populations and the difficulties of access to them, we have tried to obtain the representation of the population by percentages rather than mathematical formulas, as indicated by Bugeda [15]. In this sense it is clear the following incidents:

- The population of coaches coincides. However there is a first technical coach per team having 8 teams, plus an assistant coach in one team, representing a total of 9 .

- Players were given the questionnaire at the hotel. The questionnaire was taken back the day after.

- The questionnaire was given to 4 managers, however only one filled in it as they did not have time to help with the project. 
- The competition lasted 4 days. The questionnaire was given to the fans at half time during the quarter final games.

- The questionnaire was given to 6 (12 referees) out of 8 pairs of referees. Only 9 of them participated in the study, as the other 3 did not give it back.

- The questionnaire was given to 2 out of 8 (1 per team) physiotherapists. They were continuously working after the matches.

- There were 15 accredited journalists, 6 of them foreign. The questionnaire was given to those who had the Spanish language as mother tongue. Only 6 gave it back.

\subsection{Variables}

The variables of this study are shown in the Table 2.

\begin{tabular}{ll}
\multicolumn{2}{c}{ Table 2. Types of variables used in the study } \\
\hline Type of variable & - Gender \\
& - Occupation \\
Categorical/Attributive & Q Edalification \\
& - Educational Qualification \\
Quantitative & - Review about rules changes \\
& Throw-in before 2006 \\
According dimensions & - Kick-in after 2006 \\
& - Corner before 2006 \\
& - Corner after 2006 \\
\hline
\end{tabular}

\subsection{Questionnaire Design}

The instrument must meet two basic requirements of validity and reliability. To Latiesa [16] validity refers to "the process used really measures what is intended to measure and purpose refers to the property of the instrument that produces the same results in different tests.” In this sense Morales Vallejo [17] states that occurs when "an instrument is valid when it measures what it purports to measure him.” As for reliability, “A collection instrument completely reliable data is one that if used twice the same circumstance, produce identical data" [18]. In particular, for the study of the psychometric properties of the questionnaire have proceeded to calculate the reliability and validity by:

A. Items Analysis

a. Homogeneity Index

b. Validation Study

c. Literature Review

d. Validation by Experts

e. Pilot Study

f. Factor Analysis

B. Reliability of the questionnaire

a. Cronbach's alpha test

The instrument has 30 items (without those that relate to socio-demographic variables) that are answered with a Likert scale. The guidelines described by Valdivia-Moral, Molero, Campoy and Zagalaz [19] were followed to study the validity. Thus, the scale was sent to a group of expert reviewers to achieve the validity of its content who evaluated the degree of understanding of the items and their suitability to the study. These experts were PhD university professors from both Spanish and international agencies. Then we proceeded to the completion of a pilot study which allowed us to evaluate the validity and reliability of understanding of the instrument. Once administered the instrument, we proceeded to score and analyze using the statistical package for Windows SPSS.19. Likewise, the statistical tests necessary to achieve the construct validity and reliability were performed. The characteristics of this study do not make it possible for reliability through a test-retest-test, therefore the Cronbach's alpha test [20] was used.

Different statistical tests to achieve validity were performed, highlighting the KMO test and Bartlett's test of sphericity, 2) Model of principal component 3) Varimax rotation. These tests, in addition to eliminating those items that decreased the Cronbach alpha coefficient, led to the dimensions and variables shown in Table 3.

Table 3. Questionnaire design "Loss of Entertainment in Spanish futsal: rules changes in Throw-ins and Corners" (PEFSE)

\begin{tabular}{ll}
\hline VARIABLES & TYPE \\
\hline Gender & 1 closed question \\
Age & 1 closed question \\
Occupation & 1 closed question \\
Opinions generated with the rules changes & 7 closed questions \\
Throw-in (hands) before 2006 & 7 opened questions \\
Kick-ins (feet) after 2006 & 7 opened questions \\
Corner before 2006 & 7 closed questions \\
Corner after 2006 & 7 closed questions \\
\hline
\end{tabular}

\section{Results}

\subsection{Items Analysis}

All items were answered with minimum values of 1 and maximum of 5 . Likewise items with larger standard deviation were numbered $1,2,3,11$ and 27. Those who have submitted lower standard deviation were 7, 8, 10 and 13.

\subsection{Analysis of Reliability}

To carry out the calculation of the reliability or internal consistency we used the coefficient $\alpha$ of Cronbach. The reliability coefficients are interpreted as a correlation, considering that higher values than 0.70 indicate high reliabilit [21]. Likewise, considering that according to Fox [18] acceptable correlations are those from 0.70 and even 0.60 , when critical review estimates are made.

Initially, the questionnaire consisted of 35 items. After application of the coefficient $\alpha$ of Cronbach, a value of .668 was obtained. It was proceeded to remove those items whose score was below .025 and negative correlation. So, we proceeded to remove a total of 5 items. This resulted in the coefficient increased to a score of .705.

\subsection{Validity Analysis}

Apart from the different tests that are performed to obtain the different types of validity (e.g. PhD expert reviewers), a factor analysis was performed. Although the KMO indicator and Bartlett's test of sphericity obtained scores (.881 and .000 , respectively) indicating that you can proceed to its completion, it was decided to maintain the initial number of dimensions and distribution of the items in each dimension, since it is a questionnaire that attempts to gather information from "before" and "after", 
of changes in the rules of futsal after 2006 and how they affect the game. Likewise, following Valdivia-Moral et al. [19], it can be highlighted that the validity rates achieved were: 1) Content validity through literature review and experts' test, 2) Educational validity, by experts' test, 3) Validity of understanding, by pilot study and, finally, 4) Construct validity, thanks to the KMO indicator and Bartlett's sphericity test.

\subsection{Analysis of Sociodemographic Variables}

The distribution of respondents in relation to the gender variable was $73.4 \%$ men and $26.6 \%$ women. As for the age of respondents, $75 \%$ of respondents were between 20 and 30 years old, $14.1 \%$ were over 30 and under 40 and finally, $10.9 \%$ were more than 40 years old. Regarding occupation, $66.3 \%$ were fans, $24 \%$ players, $3.1 \%$ were coaches, with the same percentage for the referees, journalists were $2.2 \%, 0.8 \%$ physiotherapists and finally $0.4 \%$ of the respondents were managers.

\section{Discussion}

In recent years it has investigated the changes of rules in different sports to advance the educational aspects of sport or, as in this case, to support the game. For this, the use of instruments to establish an analysis of the change of the rules is necessary. Therefore, given the lack of specific tools to analyze in futsal, it is necessary to design and develop a questionnaire to assess the loss of entertainment in futsal. This instrument will be useful to all involved in this sport (players, referees, coaches, managers, physiotherapists and spectators).

Following the later, one of the main problems of this discussion is that it is not possible to compare this study with others of the same sport. Hence, this paper can shed light on this scientific field.

The structure of the instrument has five dimensions which allow further analysis of the changes included in the regulations because each dimension corresponds to a significant change in the rules of the futsal. This detailed analysis of the rules would not have been possible if we had set the dimensions based on the statistical tests.

Regarding the psychometric properties of the instrument it is important to highlight that has a Cronbach's alpha of .705, following the recommendations of Nunnally [21] and Fox [18]. That is why it can be said that this questionnaire has high reliability. Regarding the validity, was achieved in various ways. First, the review of expert reviewers, which improved the instrument based on the contributed comments. Furthermore, the Bartlett's test of sphericity and the KMO indicator gave optimal results. Finally, the literature review and pilot test provided different types of validity to the instrument already discussed above.

As the most significant aspects obtained in the answers given by the respondents noted that the variable "change" was valued positively all rule changes: the mean was 3.57 and the mode 5, which indicated a gap between the two values. The data confirmed that there are more subjects that disagree rather than agree on this item. Furthermore, the variable "play" said that it was harder for the player to take the kick-in than the throw-in. The results shown an of average 4.03 and a mode of 5 . The data supported the conclusion that there were more subjects in disagreement with the statement of the item. Finally, the variable "player" which indicated that it was more difficult for the player to take the kick-in rather than the throw-in. The mean was 3.98 and the mode 5. Therefore, the most called options were "disagree” and "strongly disagree”.

Finally, despite not having found similar instruments in futsal, in this discussion the aim is to compare the data found with those of other authors. Thus, the study of Barbero [10], which highlights the need for reliable data on the futsal competition that may contribute to greater specificity of training and performance improvement, the instrument developed is used to compare different game situations and thus encourage training activities. On the other hand, regarding the study of Juárez, Andrés and Navarro [22], the results found are consistent with these authors about the importance of the explosive actions in futsal players, also Juárez, González and Navarro [23] highlight the sport entertainment when the maximal speed displacements in futsal players are analyzed.

\section{Conclusions}

Depending on the purpose and the results obtained it can be concluded that it has achieved a good tool to evaluate the new changes of the futsal rules. Likewise, the instrument meets the criteria of reliability and validity types. Ultimately the PEFSE has the appropriate and required psychometric properties needed in this type of surveys. Therefore, the scientific community has an instrument which allow to assess the impact of the rules introduced in the sport of futsal.

\section{References}

[1] Cachón, J., Morente, H. and Lara, A.J., “Antecedentes del fútbol sala”, Quadriceps, 1 (4). 2007.

[2] Cachón, J., Lara, A.J., Cuadrado, V. and Morente, H., "Fútbol sala escolar I. Antecedentes”, In Actas del IV Congreso Internacional y XXV Nacional de Educación Física, Universidad de Córdoba. Córdoba, 2-5 April, 2008.

[3] Rivarola, M. Fútbol Rápido o “Indoor”: Guía de Canchas Locales. El Sol de Sonoma. 2007. Available: http://elsolsonoma.com/2007/020107/Deportes. 14 Agosto 2013.

[4] Rincón, D. el, Arnal, J., Latorre, A. and Sans, A. Técnicas de investigación en Ciencias Sociales, Dykinson, Madrid, 1995.

[5] Cachón-Zagalaz, J., Rodrigo-Conde, M., Campoy-Aranda, T., Linares-Girela, D. and Zagalaz-Sánchez, M.L., "Fútbol Sala y educación. Aprendizaje de un deporte colectivo para los escolares”, Journal of Sport and Health Research, www.journalshr.com, 4(3), 145-254, 2012a.

[6] Cachón Zagalaz, J. Análisis de la incidencia en el espectáculo deportivo del nuevo reglamento del FS (2006) en España. Tesis Doctoral. Universidad de Jaén, 2010.

www.micinn.es/teseo:https://www.educacion.es/teseo/mostrarRef. do?ref=923580.

[7] Departamento Técnico, "Reglamento del Fútbol Sala”, FútbolTáctico. Revista profesional de Fútbol y Fútbol Sala, 5, 2007.

[8] Bortoli, R. Estudio de las capacidades cognoscitivas en el fútbol sala. Tesis doctoral, s/p. Universidad de León, 2000.

[9] Jiménez Jiménez, F. Estudio praxiológico de la estructura de las situaciones de enseñanza en los deportes de cooperación/oposición de espacio común y participación simultánea: balonmano y fútbol sala. Tesis doctoral, s/p. Universidad de Las Palmas de Gran Canaria. 2000.

[10] Barbero Álvarez, J.C. Desarrollo de un sistema fotogramétrico y su sincronización con los registros de frecuencia cardíaca para el análisis de la competición en los deportes de equipo. Una 
aplicación práctica para el fútbol sala. Tesis doctoral, s/p. Universidad de Granada, 2002.

[11] FIFA FUTSAL. "Reglamento FIFA FUTSAL", Fútbol-Táctico. Revista profesional de Fútbol y Fútbol Sala, 19, noviembre, 2008. Available:

http://www.futbol-

tactico.com/futbolsala/articulo.php?idedi=6\&cat=0\&id=20.

[12] López Hierro, J.V. "Jugadas a balón parado El Pozo Murcia”, Fútbol-Táctico. Revista profesional de Fútbol y Fútbol Sala, 4. 2007. Available:

http://www.futbol-

tactico.com/futbolsala/articulo.php?idedi $=6 \&$ cat $=0 \& i d=20$.

[13] Cachón, J., Campoy, T., Rodrigo, M., Linares, D. and Zagalaz, M.L. "Análisis cualitativo del cambio de las reglas de juego del fútbol sala (2006) en España”, Ágora para la EF y el Deporte, 14 (3), 332-347, 2012b.

[14] Heinemann, K. Introducción a la metodología de la investigación empírica en las ciencias del deporte, Paidotribo, Barcelona, 2003.

[15] Bugeda, J. Manual de técnicas de investigación social. Instituto de Estudios Políticos, Madrid, 1974.

[16] Latiesa, M. Validez y fiabilidad de las observaciones sociológicas. En M. García Ferrando, J. Ibáñez and F. Alvira (edts.). El análisis de la realidad social. Métodos y técnicas de investigación, Alianza, Madrid, 1994.
[17] Morales Vallejo, P. Medición de actitudes en psicología y educación, Comillas, Madrid, 2000.

[18] Fox, D. El Proceso de Investigación en Educación. Universidad de Navarra, Pamplona, 1981.

[19] Valdivia-Moral, P.A., Molero, D., Campoy, T. J. and Zagalaz, M.L. "Pensamiento coeducativo del profesorado de Educación Física: Propiedades psicométricas de una escala”, Revista Internacional de Medicina y Ciencias de la Actividad Física y del Deporte. 2013.

[20] Garrido, M.E., Zagalaz, M.L., Torres, G. and Romero, S. "Validación de un cuestionario para el análisis del comportamiento y actuación de los padres y madres en el deporte", Retos. Nuevas tendencias en Educación Física, Deporte y Recreación, 18, 71-76, 2010.

[21] Nunnally, J.C. Psychometric theory, McGraw-Hill, New York, 1978

[22] Juárez Santos-García, D., Andrés Moreno, M. and Navarro Valdivieso, F. "Relaciones entre diferentes desplazamientos en carrera a la máxima velocidad en jugadores de fútbol sala”, Red: revista de entrenamiento deportivo, 22 (1), 23-26, 2008a.

[23] Juárez Santos-García, D., González Ravé, J.M. and Navarro Valdivieso, F. "Diferencias en las medidas de diversas acciones explosivas entre futbolistas de campo y futbolistas de sala", Red: revista de entrenamiento deportivo, 22 (1) 11-16. 2008b. 